\title{
Glucocorticoid regulation of amino acid transport in primary human trophoblast cells
}

\author{
O.R. Vaughan', T.L. Powell1,2 and T. Jansson ${ }^{1}$ \\ 1Department of Obstetrics and Gynecology, University of Colorado Anschutz Medical Campus, Aurora, Colorado, USA \\ 2Department of Pediatrics, University of Colorado Anschutz Medical Campus, Aurora, Colorado, USA
}

Correspondence should be addressed to O R Vaughan: orv20@cantab.net

\begin{abstract}
Excess maternal glucocorticoids reduce placental amino acid transport and fetal growth, but whether these effects are mediated directly on the syncytiotrophoblast remains unknown. We hypothesised that glucocorticoids inhibit mechanistic target of rapamycin (mTOR) signaling and insulin-stimulated System A amino acid transport activity in primary human trophoblast (PHT) cells. Syncytialised PHTs, isolated from term placentas ( $n=15)$, were treated with either cortisol $(1 \mu \mathrm{M})$ or dexamethasone $(1 \mu \mathrm{M}), \pm$ insulin (1 nM) for $24 \mathrm{~h}$. Compared to vehicle, dexamethasone increased mRNA expression, but not protein abundance of the mTOR suppressor, regulated in development and DNA damage response 1 (REDD1). Dexamethasone enhanced insulin receptor abundance, activated mTOR complex 1 and 2 signaling and stimulated System A activity, measured by $\mathrm{Na}^{+}$-dependent ${ }^{14} \mathrm{C}$-methylaminoisobutyric acid uptake. Cortisol also activated mTORC1 without significantly altering insulin receptor or mTORC2 read-outs or System A activity. Both glucocorticoids downregulated expression of the glucocorticoid receptor and the System A transporter genes SLC38A1, SLC38A2 and SLC38A4, without altering SNAT1 or SNAT4 protein abundance. Neither cortisol nor dexamethasone affected System $L$ amino acid transport. Insulin further enhanced mTOR and System A activity, irrespective of glucocorticoid treatment and despite downregulating its own receptor. Contrary to our hypothesis, glucocorticoids do not inhibit mTOR signaling or cause insulin resistance in cultured PHT cells. We speculate that glucocorticoids stimulate System A activity in PHT cells by activating mTOR signaling, which regulates amino acid transporters posttranslationally. We conclude that downregulation of placental nutrient transport in vivo following excess maternal glucocorticoids is not mediated by a direct effect on the placenta.
\end{abstract}

\author{
Key Words: \\ - placenta \\ - maternal-fetal exchange \\ - fetal development \\ - mechanistic target of \\ rapamycin \\ - solute carrier family 38A \\ members 1,2 and 4
}

Journal of Molecular Endocrinology

(2019) 63, 239-248

\section{Introduction}

Exposure of the placenta and fetus to excess glucocorticoids is associated with reduced fetal growth and increased risk for cardiovascular and metabolic disease later in life. Despite beneficial effects on neonatal viability, repeated antenatal administration of synthetic glucocorticoids to women delivering preterm reduces birthweight (Crowther et al. 2015), increases blood pressure and impairs glucose metabolism in their children (Doyle et al. 2000, Kelly et al. 2012). Elevated endogenous cortisol concentrations, as a result of maternal stress and hypothalamic-pituitary 
adrenal axis activation, are also linked to reduced fetal growth in humans (Duthie \& Reynolds 2013). Conversely, low maternal cortisol levels in obese women are associated with fetal overgrowth (Stirrat et al. 2014, 2017). Natural and synthetic glucocorticoid administration to pregnant animals similarly reduces birth weight and alters lifelong metabolic, cardiovascular and endocrine phenotype in the offspring (Fowden et al. 2016). Maternal glucocorticoids of both exogenous and endogenous origin therefore limit fetal growth. Since the presence of the inactivating enzyme $11 \beta$-hydroxysteroid dehydrogenase type II (11ßHSD2) in the syncytiotrophoblast limits direct passage of maternal cortisol into the fetal circulation (Stirrat et al. 2018), the effects of maternal glucocorticoid excess on intrauterine development may be mediated indirectly, via effects on placental function.

Glucocorticoids may limit fetal growth by decreasing placental nutrient delivery (Fowden et al. 2015, Vaughan et al. 2017). Maternal glucocorticoid administration suppresses placental transport of neutral amino acids, mediated by System A transporters (SNATs 1, 2 and 4) (Audette et al. 2011, 2014, Vaughan et al. 2012, 2013). These transporters actively accumulate amino acids in the syncytiotrophoblast, thereby establishing fetal circulating amino acid concentrations that are 2-3-fold higher than maternal concentrations. Indeed, placental System A amino acid transport may be critical for normal fetal growth (Cramer et al. 2002) and System A activity is often reduced in the placentas of severely growthrestricted infants (Mahendran et al. 1993, Glazier et al. 1997, Shibata et al. 2008, Mando et al. 2013). Insulin and insulin-like growth factor I (IGF-I) stimulate trophoblast System A activity (Karl et al. 1992, Karl 1995, Jansson et al. 2003, Roos et al. 2009a). System A is also regulated by mechanistic target of rapamycin (mTOR) signaling, which promotes SNAT2 translocation to the syncytiotrophoblast microvillous plasma membrane (Roos et al. 2009b, Rosario et al. 2013, 2016a). In skeletal muscle, glucocorticoids inhibit insulin signaling and impair mTOR activation by upregulating transcription of the MTOR repressor, regulated in DNA damage and repair 1 (REDD1) (Wang et al. 2006, Shimizu et al. 2011). Glucocorticoids similarly enhance Redd1 expression and suppress mTOR activation in the mouse placenta in vivo (Vaughan et al. 2015), but the role of REDD1 and mTOR in glucocorticoid-regulated System A transport in human trophoblast remains unknown. We hypothesized that glucocorticoids inhibit insulinstimulated System A amino acid transport in syncytialised primary human trophoblast (PHT) cells by upregulating REDD1 expression and inhibiting mTORC1 signaling.
To test this hypothesis, PHT cells were treated with cortisol, at physiological concentrations in the maternal circulation in late pregnancy (Li et al. 2012) or dexamethasone, at concentrations achieved in maternal serum following treatment with synthetic glucocorticoids (Ballard \& Ballard 1995). Cortisol acts on both the mineralocorticoid and glucocorticoid receptors, whereas dexamethasone is a more potent synthetic glucocorticoid that acts exclusively on the glucocorticoid receptor. Human trophoblast cells express functional mineralocorticoid and glucocorticoid receptors (Driver et al. 2003, Lee et al. 2005).

\section{Methods}

\section{Human tissue collection}

All procedures were conducted with informed consent and ethical approval from the University of Colorado Institutional Review Board. Placentae $(n=15)$ were collected from vaginal deliveries or uncomplicated, nonlabored Caesarean sections at term. Clinical characteristics of the study subjects are given in Table 1. Maternal smoking was an exclusion criterion for this study. None of the subjects received antenatal glucocorticoid treatment.

\section{Isolation, culture and treatment of primary human trophoblast cells}

Primary cytotrophoblasts were isolated from dissected villous tissue by trypsin digestion and discontinuous Percoll gradient separation, as described previously (Kliman et al. 1986, Roos et al. 2009b). Isolated cells were plated at $1.4 \times 10^{6}$ per well in six-well plates and cultured in a 1:1 mixture of Dulbecco's modified Eagle's medium (DMEM, 25 mM glucose) and Ham's F12 medium (10 mM glucose) with $10 \%$ fetal bovine serum, $2 \mathrm{mM}$ glutamine, $50 \mu \mathrm{g} / \mathrm{mL}$ gentamicin, $60 \mu \mathrm{g} / \mathrm{mL}$ penicillin and $100 \mu \mathrm{g} / \mathrm{mL}$ streptomycin. Cells were washed and the media was changed $18 \mathrm{~h}$ after isolation and daily thereafter. An aliquot of spent medium was collected each day for measurement

Table 1 Clinical characteristics of study subjects.

\begin{tabular}{l} 
Characteristic \\
\hline$n$ \\
Maternal body mass index $\left(\mathrm{kg} / \mathrm{m}^{2}\right)$ \\
Gestational age at delivery $(\mathrm{wk})$ \\
Delivery type (number vaginal) \\
Infant sex (number of females) \\
Birth weight (kg) \\
Placenta weight $(\mathrm{g})$
\end{tabular}

\begin{tabular}{c}
\hline Value \\
\hline 15 \\
$24.1 \pm 1.2$ \\
$39.6 \pm 0.2$ \\
7 \\
8 \\
$3.31 \pm 0.06$ \\
$612 \pm 34$ \\
\hline
\end{tabular}

Continuous variables presented as mean \pm S.E.M. 
of human chorionic gonadotrophin (hCG) concentration by ELISA (IBL America, Minneapolis, MN, USA). At $66 \mathrm{~h}$ in culture, either cortisol ( $1 \mu \mathrm{M}, \mathrm{H} 0888$, Sigma-Aldrich), dexamethasone ( $1 \mu \mathrm{M}, \mathrm{D} 2915$, Sigma-Aldrich), or vehicle (DMEM) was added to the culture medium for $24 \mathrm{~h}$. To determine the effect of the glucocorticoids on insulin signaling and insulin-stimulated amino acid transport, cells were concurrently treated with bovine insulin (1 nM, I0516, Sigma-Aldrich).

\section{Gene expression and protein abundance}

For analysis of geneexpression $(n=9$ placentas; four male, five female), RNA was extracted from PHT cells lysed in guanidine isothiocyanate following $24 \mathrm{~h}$ of hormone treatment by ethanol precipitation and spin column separation. One microgram of extracted RNA was reverse transcribed to CDNA and quantitative RT-PCR was performed to determine the relative expression of genes encoding REDD1 (REDD1, Taqman probe Hs01111686_g1), insulin receptor (INSR, Taqman probe Hs00961557_m1), glucocorticoid receptor (NR3C1, F: AAACCTTACTGCTTCTCTCTTCA, R: GTTAAGGAGATTTTCAACCACTTC; Gutling et al. 2016), SNAT1 (SLC38A1, F: GTGTATGCTTTACCCACCATTGC, R: GCACGTTGTCATAGAATGTCAAGT; Audette et al. 2014), SNAT2 (SLC38A2, Taqman probe Hs01089954_m1) and SNAT4 (SLC38A4, F:TTGCCGCCCTCTTTGGTTAC, R: GAGGACAATGGGCACAGTTAGT; Audette et al. 2014). Expression of the target transcripts was normalized to ribosomal protein S29 (RPS29, Taqman probe Hs03004310_ g1) expression using the ddCt method. Average Ct values for RPS29 were not affected by cell treatment (mean \pm S.E.M., control 25.3 \pm 0.3 , cortisol 25.3 \pm 0.4 , dexamethasone $25.0 \pm 0.3$, insulin $25.2 \pm 0.2$, cortisol+insulin $25.2 \pm 0.3$,

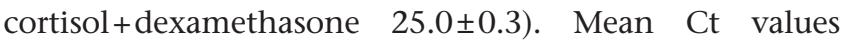
for the targets of interest were as follows: REDD1 28.2, INSR 26.0, NR3C1 25.5, SLC38A1 20.0, SLC38A2 27.4, SLC38A4 30.9.

Trophoblast abundance of glucocorticoid, insulin, mTOR signaling proteins, SNAT1 and SNAT4 was determined by Western blot following $24 \mathrm{~h}$ of hormone treatment ( $n=6$ placentas; three male, three female). Protein lysates, containing protease and phosphatase inhibitors, were resolved by SDS-PAGE under denaturing, reducing conditions and then transferred to PVDF membranes. Following blocking in 5\% bovine-serum albumin, membranes were incubated with primary antibodies targeting glucocorticoid receptor (Cell Signaling Technologies), insulin receptor $\beta$ (Santa Cruz Biotechnology), REDD1, phosphorylated (Ser235/236) and total S6 ribosomal protein (S6), phosphorylated (Ser473) and total Akt, phosphorylated (Thr202/Tyr204) and total extracellular signal-regulated kinase 1/2 (ERK1/2, all Cell Signaling Technologies), SNAT1 (AV43810, Sigma-Aldrich) and SNAT4 (Eurogentec). Abundances of cytokeratin 7 and vimentin were also assessed relative to crude placental homogenate, as markers of trophoblast and mesenchymal cells (MA5-11986, Invitrogen and ab20346). Membranes were then washed and incubated with a horseradishperoxidase-linked, species-specific secondary antibody and protein bands were visualized using enhanced chemiluminescence reagents and an automated image acquisition system (G:BOX, Syngene, Cambridge, UK). Protein abundance was quantified by band densitometry (total fluorescence, GeneTools, Syngene) and amido black staining was used as a loading control.

\section{Amino acid uptake}

System A and System L-mediated amino acid transport activity was also measured in syncytialised PHT cells ( $n=9$ placentas; five male, four female) after $24 \mathrm{~h}$ of hormone treatment as the rate of $\mathrm{Na}^{+}$-dependent ${ }^{14} \mathrm{C}$-methylaminoisobutyric acid (MeAIB) uptake and 4-amino-norbornane carboxylic acid $(\mathrm{BCH})$-inhibitable ${ }^{3} \mathrm{H}$-leucine uptake, as described previously (Roos et al. 2009b). Briefly, cells were washed and then incubated in Tyrode's buffer containing $20 \mu \mathrm{M}{ }^{14} \mathrm{C}$-MeAIB and 12.5 $\mathrm{nM}{ }^{3} \mathrm{H}$-leucine for $8 \mathrm{~min}$. Non-mediated tracer uptake was determined in parallel by incubating cells with $\mathrm{Na}^{+}$-free Tyrode's buffer containing BCH. In both cases, uptake was terminated by washing with ice-cold, $\mathrm{Na}^{+}-$ free Tyrode's buffer. Cells were lysed in distilled water to release intracellular tracer, which was quantified by liquid scintillation counting then corrected for protein content, determined by Lowry assay. The rate of transportermediated tracer uptake was determined as the difference between total uptake, in the presence of $\mathrm{Na}^{+}$, and nonmediated uptake. Preliminary experiments established that radiotracer uptake was linear with respect to time up to $10 \mathrm{~min}$ of incubation; therefore, the rate of uptake was quantified at $8 \mathrm{~min}$ in all treatment groups.

\section{Statistical analysis}

Data are reported as mean \pm S.E.M. The main effects of glucocorticoid and insulin treatment on trophoblast amino acid uptake, gene and protein expression were determined by two-way ANOVA with repeated-measures within each primary cell preparation (each placenta). 
When there was an overall effect of glucocorticoid treatment, Holm-Sidak post hoc tests were performed for pairwise comparison of vehicle, cortisol and dexamethasone treatments. When there was an overall effect of insulin treatment, the simple effect of insulin within each level of glucocorticoid treatment (vehicle, cortisol, dexamethasone) was determined by HolmSidak test. When there was a significant interaction between glucocorticoid and insulin effects, Holm-Sidak post-tests were performed for both factors. The effect of dexamethasone on SNAT1 and SNAT4 abundance was determined by Student's $t$-test. $P<0.05$ was considered statistically significant.

\section{Results}

\section{Characterisation of isolated primary human trophoblast cells}

In the isolated placental cell preparations, mean daily hCG secretion rate into the medium increased over the course of the culture period, consistent with trophoblast syncytialisation by $66 \mathrm{~h}$ post isolation (Fig. 1A). Immunoblotting confirmed that the cultured cells expressed the trophoblast marker cytokeratin 7 , but not the mesenchymal cell marker, vimentin (Fig. 1B).

\section{Glucocorticoid and insulin receptor signaling}

Cortisol and dexamethasone induced qualitatively similar changes in gene and protein expression in PHT cells, although the effects of dexamethasone were greater in magnitude. REDD1 gene expression was greater in cortisol- (+27\%) and dexamethasone-treated (+56\%) cells compared to vehicle-treated controls (Fig. 2B) but neither glucocorticoid altered trophoblast REDD1 protein abundance (Fig. 2C). Dexamethasone significantly increased IR $\beta$ protein abundance but not INSR mRNA expression in the PHT cells, whereas cortisol did not affect either IR $\beta$ nor INSR mRNA expression (Fig. 2D and E). Consistent with this insulin receptor upregulation, glucocorticoid treatment enhanced phosphorylation of the mTORC1 and mTORC2 downstream targets, S6 and Akt, without any change in total $\mathrm{S} 6$ or Akt abundance (Fig. 3A, B, C, D and E). Moreover, glucocorticoids did not impair insulin receptor signaling, as insulin independently increased S6 and Akt phosphorylation in vehicle- and glucocorticoid-treated cells (Fig. 3B and D). Insulin reduced IR $\beta$ abundance in dexamethasone-treated cells and downregulated INSR expression irrespective of
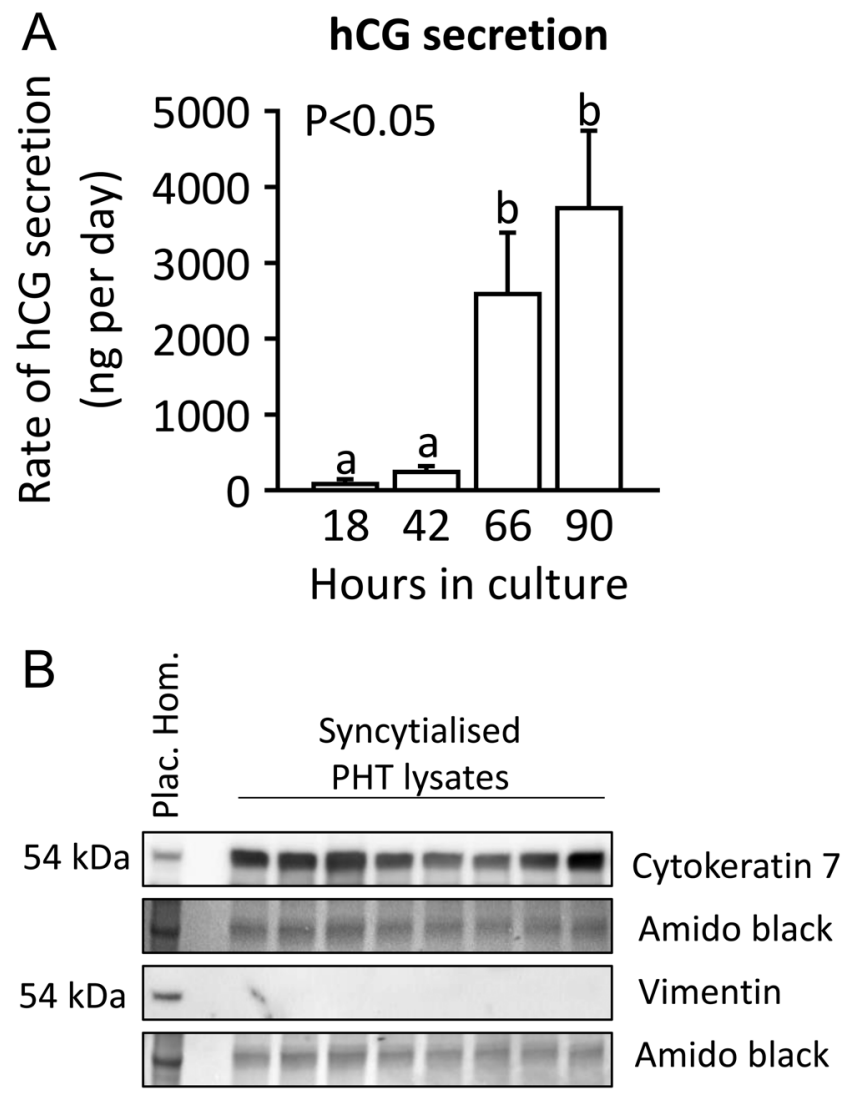

Figure 1

Characterisation of primary human trophoblast cells. (A) Daily rate of hCG secretion into the culture medium by PHT cells at 18, 42, 66 and $90 \mathrm{~h}$ after isolation. Overall effect of time point determined by one-way ANOVA with Holm-Sidak post hoc. Differing superscripts $a$, b indicate significantly different time points. $n=9$ placentas. Mean + S.E.M. (B) Western blots of cytokeratin 7 (trophoblast marker) and vimentin (mesenchyme marker) in lysates collected from syncytialised PHT cells $90 \mathrm{~h}$ after isolation,

compared to crude placental homogenate (Plac. Hom.).

glucocorticoid treatment but did not affect REDD1/REDD1 gene expression or protein abundance (Fig. 2). There was no effect of either insulin or glucocorticoids on phosphorylated or total ERK1/2 abundance (Fig. 3F and $\mathrm{G})$. Glucocorticoid receptor mRNA and protein abundance was lower in glucocorticoid-treated compared to vehicle-treated PHTs, but was not affected by insulin (Fig. 2F and G).

\section{Amino acid transport and transporter expression}

Overall, glucocorticoids significantly stimulated System A amino acid transport in PHT cells, such that the rate of 14C-MeAIB uptake was higher in dexamethasone-treated trophoblasts than in cortisol-treated or control cells, irrespective of insulin treatment (Fig. 4A, B, C). Both cortisol and dexamethasone increased basal ${ }^{14} \mathrm{C}$-MeAIB uptake, 
A

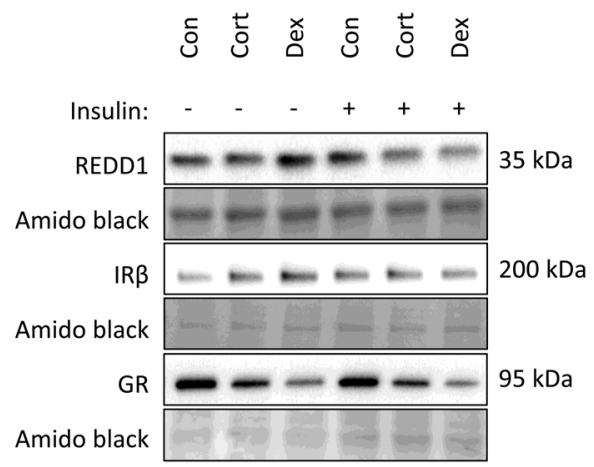

B

REDD1 MRNA

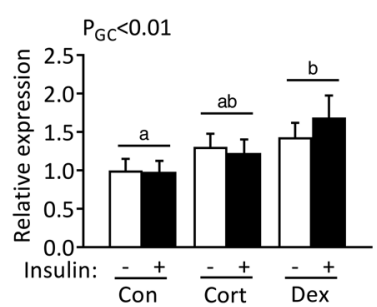

C

REDD1

$\mathrm{D}$

INSR mRNA
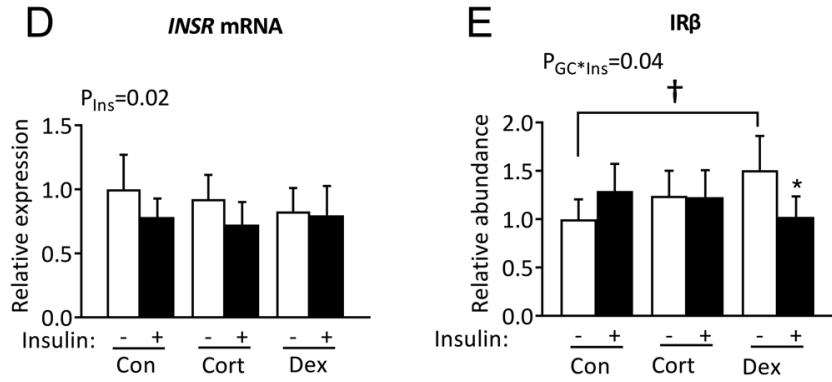

$\mathrm{F}$ NR3C1 mRNA

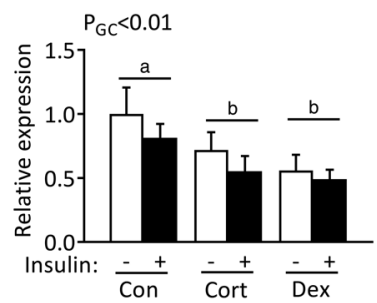

G

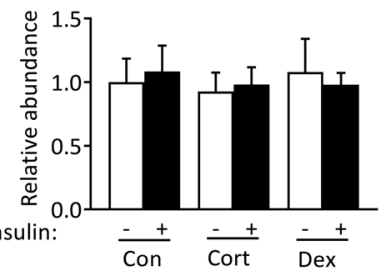

$P_{G C}<0.01$

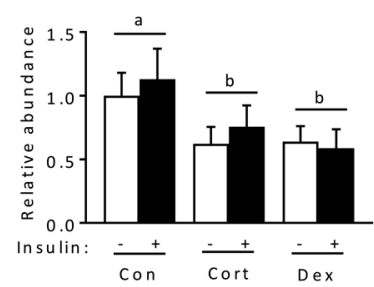

Figure 2

Effects of glucocorticoids and insulin on REDD1 and insulin receptor abundance. Representative Western blots (A), gene expression (B, D and F) and protein abundance (C, E and G) of REDD1 and insulin receptor in syncytialised primary human trophoblast cells treated with vehicle (Con), cortisol (Cort, $1 \mu \mathrm{M})$ and dexamethasone (Dex, $1 \mu \mathrm{M})$, \pm insulin (concentration, $1 \mathrm{nM})$. Effects of glucocorticoid $\left(\mathrm{P}_{\mathrm{GC}}\right)$, insulin $\left(\mathrm{P}_{\text {ins }}\right)$ and interaction $\left(\mathrm{P}_{\mathrm{GC} * \mid n)}\right)$ were determined by two-way ANOVA with repeated measures and significances $(P<0.05)$ are provided in the figure. Differing superscripts $a, b$ indicate significantly different glucocorticoid treatment groups, * indicates significant simple effect of insulin and $t$ indicates significant simple effect of dexamethasone by Holm-Sidak post hoc. $n=9$ placentas (gene expression), $n=6$ placentas (protein). Mean \pm S.E.M.

A
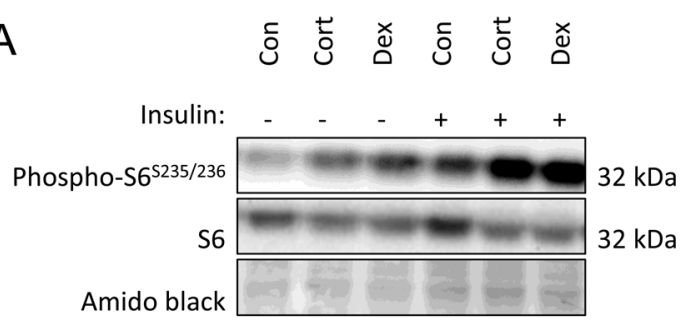

Phospho-Akt ${ }^{\mathrm{S} 473}$

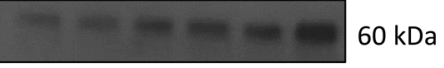

Amido black

Akt

$\mathrm{An}=\mathrm{m}-\mathrm{m}$ $60 \mathrm{kDa}$

Phospho-ERK1/2 ${ }^{\text {Thr202/Tyr204 }}$

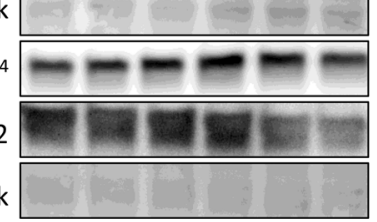

$42 / 44 \mathrm{kDa}$

Amido black

$42 / 44 \mathrm{kDa}$

B

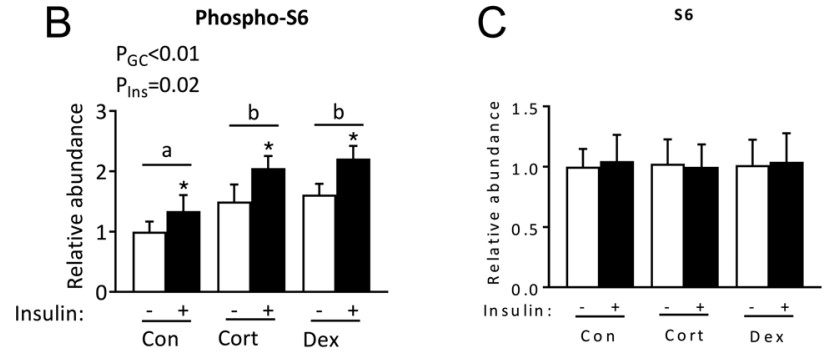

C

s6

D

Phospho-Akt

E

Akt
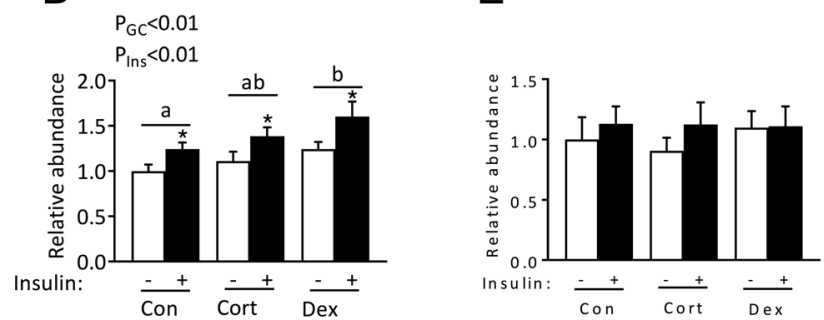

$\mathrm{F}$

G

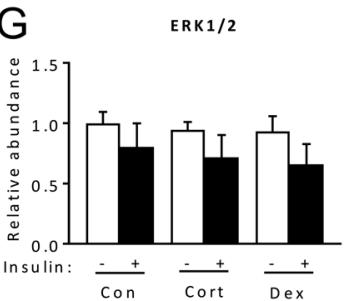

Figure 3

Effects of glucocorticoids and insulin on mTORC1, mTORC2 and ERK1/2 signaling. (A) Representative Western blots and (B, C, D, E, F and G) phosphorylated and total protein abundance for readouts of mTORC1, mTORC2 and ERK1/2 signaling in syncytialised primary human trophoblast cells treated with vehicle (Con), cortisol (Cort, $1 \mu \mathrm{M})$ and dexamethasone (Dex, $1 \mu \mathrm{M}), \pm$ insulin (concentration, $1 \mathrm{nM}$ ). Effects of glucocorticoid $\left(\mathrm{P}_{\mathrm{GC}}\right)$, insulin $\left(\mathrm{P}_{\text {ins }}\right)$ and interaction $\left(\mathrm{P}_{\mathrm{GC}{ }^{*} n \mathrm{~ns}}\right)$ were determined by two-way ANOVA with repeated measures and significances $(P<0.05)$ are provided in the figure. Differing superscripts $a, b$ indicate significantly different glucocorticoid treatment groups, * indicates significant simple effect of insulin by Holm-Sidak post hoc. $n=6$ placentas. Mean \pm S.E.M. 
A

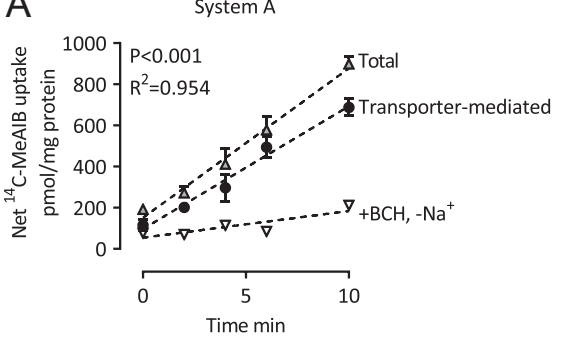

C $\quad P_{G C}<0.01, P_{\text {Ins }}<0.01$

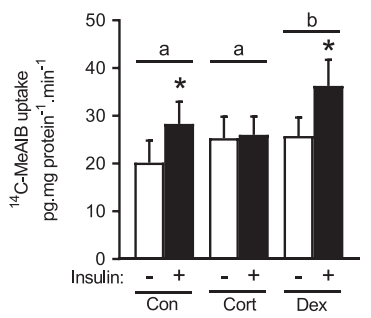

B System L

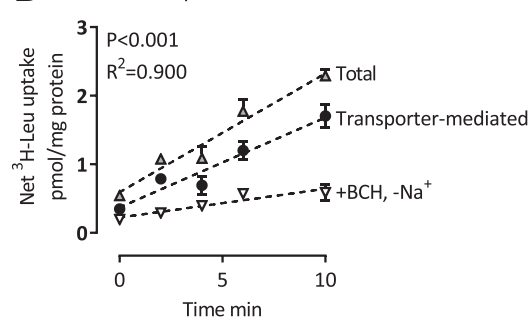

D

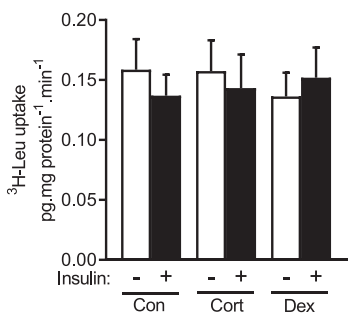

Figure 4

Effects of glucocorticoids and insulin on System A and System L amino acid transport. System A-mediated ${ }^{14} \mathrm{C}$-methylaminoisobutyric acid uptake (A and C) and System L-mediated ${ }^{3} \mathrm{H}$-leucine uptake ( $B$ and $D$ ) in syncytialised primary human trophoblast cells. (A and B) Time-course of total, non-mediated (+ $\left.\mathrm{BCH},-\mathrm{Na}^{+}\right)$and transportermediated (total - non-mediated) uptake in untreated cells ( $n=3$ placentas). (C and D) Rate of uptake assessed after $8 \mathrm{~min}$ of tracer incubation in vehicle (Con), cortisol (Cort, $1 \mu \mathrm{M}$ ) and dexamethasone (Dex $1 \mu \mathrm{M})$ treated cells, \pm insulin (concentration, $1 \mathrm{nM}$ ). Effects of glucocorticoid $\left(\mathrm{P}_{\mathrm{GC}}\right)$, insulin $\left(\mathrm{P}_{\text {ins }}\right)$ and interaction $\left(\mathrm{P}_{\mathrm{GC} * \text { ns }}\right)$ were determined by two-way ANOVA with repeated measures and significances $(P<0.05)$ are provided in the figure. Differing superscripts $\mathrm{a}, \mathrm{b}$ indicate significantly different glucocorticoid treatment groups, * indicates significant simple effect of insulin by Holm-Sidak post hoc. $n=9$ placentas. Mean \pm S.E.M. in the absence of insulin $(P<0.05$ vs control without insulin, Holm-Sidak post hoc). Insulin further enhanced System A activity in vehicle- and dexamethasone-treated cells, but not in cortisol-treated cells (Fig. 4C). In contrast, both cortisol and dexamethasone reduced PHT cell expression of the amino acid transporters SLC38A1, SLC38A2 and SLC38A4, compared to vehicle-treated controls, whereas insulin did not alter amino acid transporter gene expression (Fig. 5A, B and C). Dexamethasone did not affect PHT cell total SNAT1 or SNAT4 abundance (Fig. 5D and E). Neither glucocorticoids nor insulin affected System L-mediated ${ }^{3}$ H-Leu uptake (Fig. 4D).

\section{Discussion}

Contrary to our original hypothesis, this study shows that glucocorticoids do not suppress insulin-stimulated System A amino acid transport or mTOR signaling in syncytialised primary human trophoblast. Instead, the study provides the first demonstration that glucocorticoids act additively with insulin to stimulate System A amino acid transport activity and mTOR signaling, in addition to enhancing insulin receptor abundance. Glucocorticoids downregulated System A amino acid transporter gene expression but did not alter total SNAT protein abundance.

Glucocorticoid stimulation of basal System A activity in primary human trophoblast cells in this study is in line with previous reports in choriocarcinoma cells and placental villous explants treated with cortisol or dexamethasone (Jones et al. 2006, Audette et al. 2010). The micromolar cortisol and dexamethasone concentrations used in culture in all these studies were designed to reflect those in the circulation of pregnant women without treatment (Li et al. 2012) or following antenatal synthetic glucocorticoid administration (Ballard \& Ballard 1995). Higher concentrations of dexamethasone have also been shown previously to stimulate System A activity in syncytialised primary human trophoblast (Karl et al. 1992). We extend these observations to show that this physiological effect is specific to System A activity, because there was no effect of either cortisol or dexamethasone on System L-mediated leucine uptake. Our study also demonstrates that the effects of cortisol and dexamethasone on basal System A activity are qualitatively similar, suggesting that they are mediated by the glucocorticoid receptor rather than the mineralocorticoid receptor, which is bound with lower affinity by dexamethasone than cortisol (Rogerson et al. 1999). The lesser effect of cortisol, compared to dexamethasone, may reflect its lower glucocorticoid receptor affinity and inactivation by 11BHSD2 in the trophoblast (Stirrat et al. 2018). Although the analyses in this study used similar numbers of placentas of male or female sex, and from vaginal or cesarean deliveries, we cannot exclude the possibility that glucocorticoid regulation of trophoblast amino acid transport differs by sex or delivery type. Labor inhibits mTOR signaling in the human placenta (Lager et al. 2014) and exogenous testosterone reduces placental SNAT1 expression in rats (Sathishkumar et al. 2011), but whether these factors modulate the response to glucocorticoids remains unstudied.

Increased in vitro System A activity was not mediated by a transcriptional or translational effect on 
A

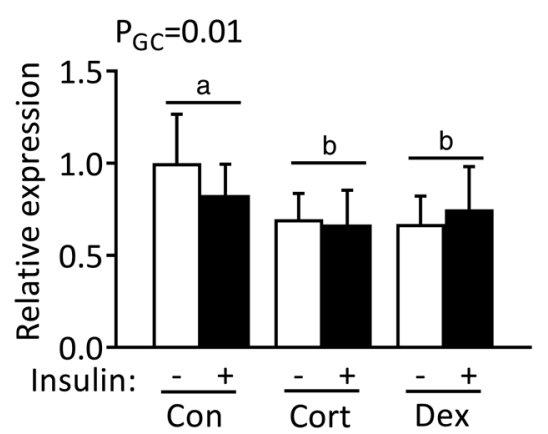

B

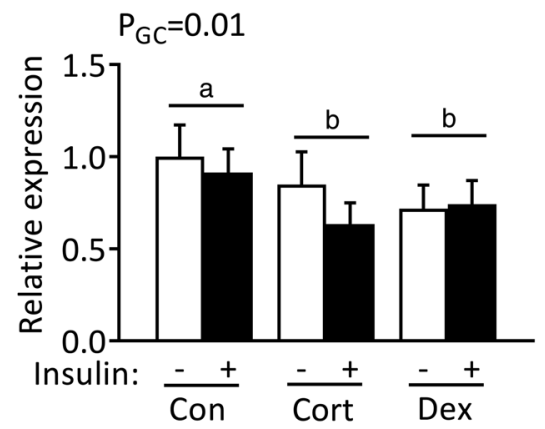

C

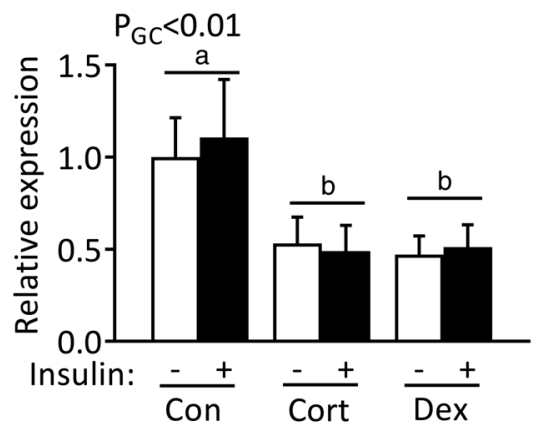

D

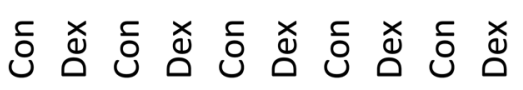

SNAT1

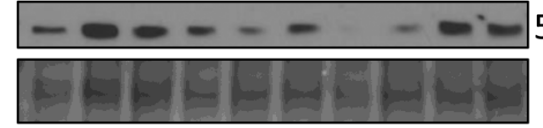

SNAT1

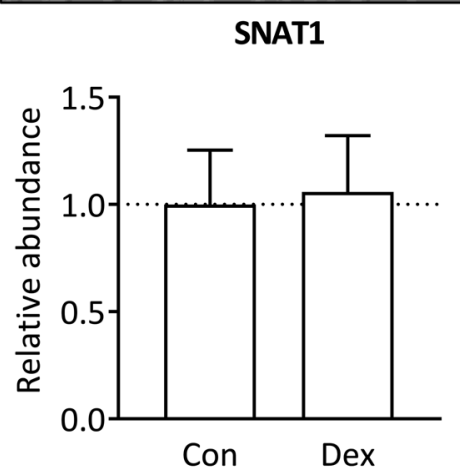

E

$50 \mathrm{kDa}$

Amido black

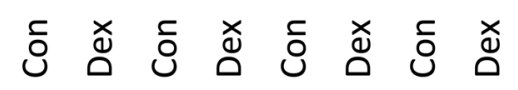

Amido black

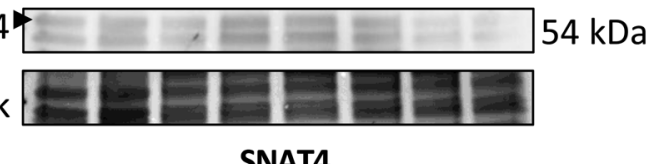

SNAT4

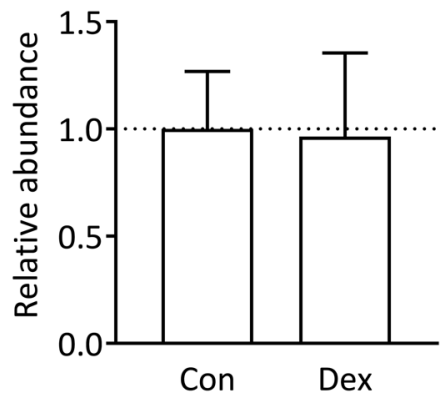

Figure 5

Effects of glucocorticoids and insulin on System A transporter gene and protein expression. (A) Representative Western blot, (B, D and E) mRNA expression and (C) protein abundance of System A transporters in syncytialised primary human trophoblast cells treated with vehicle (Con), cortisol (Cort, $1 \mu \mathrm{M}$ ) and dexamethasone (Dex, $1 \mu \mathrm{M}), \pm$ insulin (concentration, $1 \mathrm{nM}$ ). Effects of glucocorticoid $\left(\mathrm{P}_{\mathrm{GC}}\right)$, insulin $\left(P_{\text {ins }}\right)$ and interaction $\left(P_{G C * i n s}\right)$ were determined by two-way ANOVA with repeated measures and significances $(P<0.05)$ are provided in the figure. Differing superscripts a, $\mathrm{b}$ indicate significantly different glucocorticoid treatment groups, * indicates significant simple effect of insulin by Holm-Sidak post hoc. $n=5$ placentas (gene expression), $n=9$ placentas (protein). Mean \pm s.E.M.

SLC38A/SNAT transporter gene expression or protein abundance. Indeed, glucocorticoid treatment downregulated SLC38A1, SLC38A2 and SLC38A4 expression, in contrast with previous studies in human placental villous explants showing that these genes are unaffected by dexamethasone (Audette et al. 2010). The discrepant RNA findings of these two studies most likely reflects the more complex cellular composition of placental villous explants, including trophoblast, mesenchymal and endothelial cells, and therefore, suggest that the suppressive effect of dexamethasone on transporter gene expression is specific to the syncytiotrophoblast. Nonetheless, dexamethasone had no effect on SNAT1 or SNAT4 protein abundance in either this or the previous study (Audette et al. 2010). We were unable to measure SNAT2 protein abundance in PHT cell lysates and therefore cannot exclude the possibility of greater synthesis or stability of this transporter, but this is unlikely given the reduced SLC38A2 mRNA expression. Instead, the data indicate that glucocorticoids may regulate amino acid transporters at the posttranslational level, a hypothesis supported by the demonstration that cortisol promotes trafficking of SNAT2 in choriocarcinoma cells (Jones et al. 2006). Certainly, both glucocorticoids resulted in a robust activation of mTORC1 and mTORC2 signaling pathways, which regulate trophoblast System A-mediated amino acid uptake by influencing the trafficking of specific transporter isoforms to the plasma membrane (Rosario et al. 2013). Our data therefore also imply that protein and gene expression of nutrient transporters in total cell lysates provides only limited information on transport activity given that trophoblast nutrient transporters are 
often subjected to posttranslational regulation and these proteins mediate transport only when inserted in the plasma membrane (Rosario et al. 2013, 2016b).

We originally hypothesized that glucocorticoid treatment suppresses trophoblast mTOR signaling by upregulating the mTOR suppressor REDD1. Cortisol and dexamethasone both upregulated REDD1 mRNA in PHT cells, in line with the effect of exogenous corticosterone administration on placental Redd1 expression in mice (Vaughan et al. 2015). However, increased levels of the REDD1 transcript in this study were not accompanied by a corresponding increase in the translated protein, suggesting that REDD1 may also be subject to posttranscriptional or post-translational control in trophoblast. Certainly, the REDD1 protein is highly labile in vitro, with a half-life of 5-7 min, and subject to rapid ubiquitination and proteasomal degradation (Katiyar et al. 2009, Tan \& Hagen 2013).

In the absence of suppression by REDD1, the activation of mTORC1 and mTORC2 signaling and phosphorylation of S6 and Akt downstream may relate to increased insulin receptor abundance in the glucocorticoid treated PHT cells. Although glucocorticoids commonly impair peripheral post-receptor insulin signaling, they enhance insulin receptor abundance in lymphocytes (Fantus et al. 1982), fibroblasts (Knutson 1986) and in the sheep placenta in vivo (Vaughan et al. 2016). In agreement with our finding of IR $\beta$ protein upregulation without increased INSR mRNA in dexamethasone-treated trophoblasts, the glucocorticoid-induced increase in total insulin receptor abundance in fibroblasts is coincident with slower degradation but no change in synthesis of the insulin receptor (Knutson 1986). Greater insulin receptor abundance at the trophoblast cell surface following dexamethasone treatment would be expected to increase intracellular insulin signaling in the presence of basal medium insulin concentrations, and therefore, further enhance signaling when exogenous insulin was added. We therefore speculate that the acute increase in System A uptake in glucocorticoid-treated primary human trophoblast cells is secondary to insulin receptor upregulation. This effect is additive with the mTORdependent effect of insulin to promote SNAT2 protein translation and translocation to the trophoblast plasma membrane (Rosario et al. 2013). The effect of insulin on System A was less marked in cortisol-treated cells, suggesting that cortisol binding to the mineralocorticoid receptor antagonizes the mTOR stimulatory glucocorticoid effect, for example by impinging elsewhere in the insulin receptor signaling cascade (Hitomi et al. 2007, Sherajee et al. 2012). Moreover, glucocorticoids and insulin did not influence trophoblast ERK1/2 phosphorylation, which is normally positively regulated by insulin receptor signaling, suggesting that compensatory deactivating events also occurred in the growth promoting, mitogenactivated protein kinase arm of the cascade.

Taken together, the data demonstrate that glucocorticoids acutely stimulate System A amino acid transport and do not cause insulin resistance in cultured primary human trophoblast cells. These effects are opposite to the established suppressive action of in vivo glucocorticoid overexposure on placental System A transport capacity and fetal growth (Audette et al. 2011, 2014, Vaughan et al. 2012). Glucocorticoid suppression of trophoblast SLC38A gene transcription, demonstrated here after $24 \mathrm{~h}$, may ultimately outweigh the acute stimulatory effect to reduce steady state membrane transporter abundance and System A activity in the long term. Indeed, reduced placental System A activity in women given antenatal glucocorticoids is manifested more than two weeks after treatment and not within $24 \mathrm{~h}$ of administration (Audette et al. 2014). Alternatively, our data are consistent with the model that downregulation of placental nutrient transport in vivo following excess maternal glucocorticoids is not mediated by a direct effect on the placenta.

\section{Declaration of interest}

The authors declare that there is no conflict of interest that could be perceived as prejudicing the impartiality of the research reported.

\section{Funding}

This study was supported by NIH (R01HD68370) and by NIH/NCATS Colorado CTSA Grant Number UL1 TR002535. Contents are the authors' sole responsibility and do not necessarily represent official $\mathrm{NIH}$ views.

\section{Acknowledgements}

The authors are grateful to the staff of the Perinatal Clinical and Translational Research Centre of the University of Colorado and to the study participants.

\section{References}

Audette MC, Challis JR, Jones RL, Sibley CP \& Matthews SG 2011 Antenatal dexamethasone treatment in midgestation reduces system A-mediated transport in the late-gestation murine placenta. Endocrinology 152 3561-3570. (https://doi.org/10.1210/en.2011-0104)

Audette MC, Challis JRG, Jones RL, Sibley CP \& Matthews SG 2014 Synthetic glucocorticoid reduces human placental system A transport in women treated With antenatal therapy. The Journal of Clinical 
Endocrinology \& Metabolism 99 E2226-E2233. (https://doi org/10.1210/jc.2014-2157)

Audette MC, Greenwood SL, Sibley CP, Jones CJP, Challis JRG, Matthews SG \& Jones RL 2010 Dexamethasone stimulates placental system A transport and trophoblast differentiation in term villous explants. Placenta 31 97-105. (https://doi.org/10.1016/j. placenta.2009.11.016)

Ballard PL \& Ballard RA 1995 Scientific basis and therapeutic regimens for use of antenatal glucocorticoids. American Journal of Obstetrics \& Gynecology 173 254-262. (https://doi.org/10.1016/00029378(95)90210-4)

Cramer S, Beveridge M, Kilberg M \& Novak D 2002 Physiological importance of system A-mediated amino acid transport to rat fetal development. American Journal of Physiology. Cell Physiology 282 C153-C160. (https://doi.org/10.1152/ajpcell.2002.282.1.C153)

Crowther CA, Mckinlay CJ, Middleton P \& Harding JE 2015 Repeat doses of prenatal corticosteroids for women at risk of preterm birth for improving neonatal health outcomes. Cochrane Database Systematic Reviews Cd003935. (https://doi.org/10.1002/14651858. CD003935.pub4)

Doyle LW, Ford GW, Davis NM \& Callanan C 2000 Antenatal corticosteroid therapy and blood pressure at 14 years of age in preterm children. Clinical Science 98 137-142. (https://doi. org/10.1042/cs0980137)

Driver PM, Rauz S, Walker EA, Hewison M, Kilby MD \& Stewart PM 2003 Characterization of human trophoblast as a mineralocorticoid target tissue. Molecular Human Reproduction 9 793-798. (https://doi. org/10.1093/molehr/gag091)

Duthie L \& Reynolds RM 2013 Changes in the maternal hypothalamicpituitary-adrenal axis in pregnancy and postpartum: influences on maternal and fetal outcomes. Neuroendocrinology 98 106-115. (https://doi.org/10.1159/000354702)

Fantus IG, Saviolakis GA, Hedo JA \& Gorden P 1982 Mechanism of glucocorticoid-induced increase in insulin receptors of cultured human lymphocytes. Journal of Biological Chemistry 257 8277-8283.

Fowden AL, Forhead AJ, Sferruzzi-Perri AN, Burton GJ \& Vaughan OR 2015 Review: endocrine regulation of placental phenotype. Placenta 36(Supplement 1) S50-S59. (https://doi.org/10.1016/j. placenta.2014.11.018)

Fowden AL, Valenzuela OA, Vaughan OR, Jellyman JK \& Forhead AJ 2016 Glucocorticoid programming of intrauterine development. Domestic Animal Endocrinology 56(Supplement) S121-S132. (https:// doi.org/10.1016/j.domaniend.2016.02.014)

Glazier JD, Cetin I, Perugino G, Ronzoni S, Grey AM, Mahendran D, Marconi AM, Pardi G \& Sibley CP 1997 Association between the activity of the system A amino acid transporter in the microvillous plasma membrane of the human placenta and severity of fetal compromise in intrauterine growth restriction. Pediatric Research 42 514-519. (https://doi.org/10.1203/00006450-199710000-00016)

Gutling H, Bionaz M, Sloboda DM, Ehrlich L, Braun F, Gramzow AK, Henrich W, Plagemann A \& Braun T 2016 The importance of selecting the right internal control gene to study the effects of antenatal glucocorticoid administration in human placenta. Placenta 44 19-22. (https://doi.org/10.1016/j.placenta.2016.05.011)

Hitomi H, Kiyomoto H, Nishiyama A, Hara T, Moriwaki K, Kaifu K, Ihara G, Fujita Y, Ugawa T \& Kohno M 2007 Aldosterone suppresses insulin signaling via the downregulation of insulin receptor substrate-1 in vascular smooth muscle cells. Hypertension 50 750755. (https://doi.org/10.1161/HYPERTENSIONAHA.107.093955)

Jansson N, Greenwood SL, Johansson BR, Powell TL \& Jansson T 2003 Leptin stimulates the activity of the system A amino acid transporter in human placental villous fragments. Journal of Clinical Endocrinology \& Metabolism 88 1205-1211. (https://doi.org/10.1210/jc.2002-021332)

Jones HN, Ashworth CJ, Page KR \& Mcardle HJ 2006 Cortisol stimulates system A amino acid transport and SNAT2 expression in a human placental cell line (BeWo). American Journal of Physiology.
Endocrinology \& Metabolism 291 E596-E603. (https://doi.org/10.1152/ ajpendo.00359.2005)

Karl PI 1995 Insulin-like growth factor-1 stimulates amino acid uptake by the cultured human placental trophoblast. Journal of Cellular Physiology 165 83-88. (https://doi.org/10.1002/jcp.1041650111)

Karl PI, Alpy KL \& Fisher SE 1992 Amino acid transport by the cultured human placental trophoblast: effect of insulin on AIB transport. American Journal of Physiology 262 C834-C839. (https://doi. org/10.1152/ajpcell.1992.262.4.C834)

Katiyar S, Liu E, Knutzen CA, Lang ES, Lombardo CR, Sankar S, Toth JI, Petroski MD, Ronai Z \& Chiang GG 2009 REDD1, an inhibitor of mTOR signalling, is regulated by the CUL4A-DDB1 ubiquitin ligase. EMBO Reports 10 866-872. (https://doi.org/10.1038/embor.2009.93)

Kelly BA, Lewandowski AJ, Worton SA, Davis EF, Lazdam M, Francis J, Neubauer S, Lucas A, Singhal A \& Leeson P 2012 Antenatal glucocorticoid exposure and long-term alterations in aortic function and glucose metabolism. Pediatrics 129 e1282-e1290. (https://doi. org/10.1542/peds.2011-3175)

Kliman HJ, Nestler JE, Sermasi E, Sanger JM \& Strauss JF, 3RD 1986 Purification, characterization, and in vitro differentiation of cytotrophoblasts from human term placentae. Endocrinology 118 1567-1582. (https://doi.org/10.1210/endo-118-4-1567)

Knutson VP 1986 The acute and chronic effects of glucocorticoids on insulin receptor and insulin responsiveness. Transient fluctuations in intracellular receptor level parallel transient fluctuations in responsiveness. Journal of Biological Chemistry 261 10306-10312.

Lager S, Aye ILMH, Gaccioli F, Ramirez VI, Jansson T \& Powell TL 2014 Labor inhibits placental mechanistic target of rapamycin complex 1 signaling. Placenta 35 1007-1012. (https://doi.org/10.1016/j. placenta.2014.10.006)

Lee MJ, Wang Z, Yee H, Ma Y, Swenson N, Yang L, Kadner SS, Baergen RN, Logan SK, Garabedian MJ, et al. 2005 Expression and regulation of glucocorticoid receptor in human placental villous fibroblasts. Endocrinology 146 4619-4626. (https://doi.org/10.1210/ en.2005-0235)

Li J, Wang ZN, Chen YP, Dong YP, Shuai HL, Xiao XM, Reichetzeder C \& Hocher B 2012 Late gestational maternal serum cortisol is inversely associated with fetal brain growth. Neuroscience \& Biobehavioral Reviews 36 1085-1092. (https://doi.org/10.1016/j. neubiorev.2011.12.006)

Mahendran D, Donnai P, Glazier JD, D'Souza SW, Boyd RD \& Sibley CP 1993 Amino acid (system A) transporter activity in microvillous membrane vesicles from the placentas of appropriate and small for gestational age babies. Pediatric Research 34 661-665. (https://doi. org/10.1203/00006450-199311000-00019)

Mando C, Tabano S, Pileri P, Colapietro P, Marino MA, Avagliano L, Doi P, Bulfamante G, Miozzo M \& Cetin I 2013 SNAT2 expression and regulation in human growth-restricted placentas. Pediatric Research 74 104-110. (https://doi.org/10.1038/pr.2013.83)

Rogerson FM, Dimopoulos N, Sluka P, Chu S, Curtis AJ \& Fuller PJ 1999 Structural determinants of aldosterone binding selectivity in the mineralocorticoid receptor. Journal of Biological Chemistry 27436305 36311. (https://doi.org/10.1074/jbc.274.51.36305)

Roos S, Kanai Y, Prasad PD, Powell TL \& Jansson T 2009a Regulation of placental amino acid transporter activity by mammalian target of rapamycin. American Journal of Physiology. Cell Physiology 296 C142C150. (https://doi.org/10.1152/ajpcell.00330.2008)

Roos S, Lagerlof O, Wennergren M, Powell TL \& Jansson T 2009b Regulation of amino acid transporters by glucose and growth factors in cultured primary human trophoblast cells is mediated by mTOR signaling. American Journal of Physiology. Cell Physiology 297 C723C731. (https://doi.org/10.1152/ajpcell.00191.2009)

Rosario FJ, Dimasuay KG, Kanai Y, Powell TL \& Jansson T 2016a Regulation of amino acid transporter trafficking by mTORC1 in primary human trophoblast cells is mediated by the ubiquitin ligase Nedd4-2. Clinical Science 130 499-512. (https://doi.org/10.1042/CS20150554) 
Rosario FJ, Powell TL \& Jansson T 2016b Mechanistic target of rapamycin (mTOR) regulates trophoblast folate uptake by modulating the cell surface expression of FR-alpha and the RFC. Scientific Reports 6 31705. (https://doi.org/10.1038/srep31705)

Rosario FJ, Kanai Y, Powell TL \& Jansson T 2013 Mammalian target of rapamycin signalling modulates amino acid uptake by regulating transporter cell surface abundance in primary human trophoblast cells. Journal of Physiology 591 609-625. (https://doi.org/10.1113/ jphysiol.2012.238014)

Sathishkumar K, Elkins R, Chinnathambi V, Gao H, Hankins GD \& Yallampalli C 2011 Prenatal testosterone-induced fetal growth restriction is associated with down-regulation of rat placental amino acid transport. Reproductive Biology and Endocrinology : RB\&E 9110. (https://doi.org/10.1186/1477-7827-9-110)

Sherajee SJ, Fujita Y, Rafiq K, Nakano D, Mori H, Masaki T, Hara T, Kohno M, Nishiyama A \& Hitomi H 2012 Aldosterone induces vascular insulin resistance by increasing insulin-like growth factor-1 receptor and hybrid receptor. Arteriosclerosis, Thrombosis, \& Vascular Biology 32 257-263. (https://doi.org/10.1161/ ATVBAHA.111.240697)

Shibata E, Hubel CA, Powers RW, Von Versen-Hoeynck F, Gammill H, Rajakumar A \& Roberts JM 2008 Placental system A amino acid transport is reduced in pregnancies With small for gestational age (SGA) infants but not in preeclampsia with SGA infants. Placenta 29 879-882. (https://doi.org/10.1016/j.placenta.2008.07.001)

Shimizu N, Yoshikawa N, Ito N, Maruyama T, Suzuki Y, Takeda S, Nakae J, Tagata Y, Nishitani S, Takehana K, et al. 2011 Crosstalk between glucocorticoid receptor and nutritional sensor mTOR in skeletal muscle. Cell Metabolism 13 170-182. (https://doi. org/10.1016/j.cmet.2011.01.001)

Stirrat LI, Just G, Homer NZM, Andrew R, Norman JE \& Reynolds RM 2017 Glucocorticoids are lower at delivery in maternal, but not cord blood of obese pregnancies. Scientific Reports 7 10263. (https://doi. org/10.1038/s41598-017-10266-5)

Stirrat LI, O'Reilly JR, Riley SC, Howie AF, Beckett GJ, Smith R, Walker BR, Norman JE \& Reynolds RM 2014 Altered maternal hypothalamic-pituitary-adrenal axis activity in obese pregnancy is associated with macrosomia and prolonged pregnancy. Pregnancy Hypertension 4 238. (https://doi.org/10.1016/j.preghy.2014.03.028)

Stirrat LI, Sengers BG, Norman JE, Homer NZM, Andrew R, Lewis RM \& Reynolds RM 2018 Transfer and metabolism of cortisol by the isolated perfused human placenta. Journal of Clinical Endocrinology \& Metabolism 103 640-648. (https://doi.org/10.1210/jc.2017-02140)

Tan CY \& Hagen T 2013 mTORC1 dependent regulation of REDD1 protein stability. PLOS ONE 8 e63970. (https://doi.org/10.1371/ journal.pone.0063970)

Vaughan OR, Davies KL, Ward JW, de Blasio MJ \& Fowden AL 2016 A physiological increase in maternal cortisol alters uteroplacental metabolism in the pregnant ewe. The Journal of Physiology 594 64076418. (https://doi.org/10.1113/JP272301)

Vaughan OR, Fisher HM, Dionelis KN, Jefferies EC, Higgins JS, Musial B, Sferruzzi-Perri AN \& Fowden AL 2015 Corticosterone alters maternofetal glucose partitioning and insulin signalling in pregnant mice. Journal of Physiology 593 1307-1321. (https://doi.org/10.1113/ jphysiol.2014.287177)

Vaughan OR, Rosario FJ, Powell TL \& Jansson T 2017 Regulation of placental amino acid transport and fetal growth. Progress in Molecular Biology \& Translational Science 145 217-251. (https://doi.org/10.1016/ bs.pmbts.2016.12.008)

Vaughan OR, Sferruzzi-Perri AN, Coan PM \& Fowden AL 2013 Adaptations in placental phenotype depend on route and timing of maternal dexamethasone administration in mice. Biology of Reproduction 89 80. (https://doi.org/10.1095/biolreprod.113.109678)

Vaughan OR, Sferruzzi-Perri AN \& Fowden AL 2012 Maternal corticosterone regulates nutrient allocation to fetal growth in mice. Journal of Physiology 590 5529-5540. (https://doi.org/10.1113/ jphysiol.2012.239426)

Wang H, Kubica N, Ellisen LW, Jefferson LS \& Kimball SR 2006 Dexamethasone represses signaling through the mammalian target of rapamycin in muscle cells by enhancing expression of REDD1. Journal of Biological Chemistry 281 39128-39134. (https://doi. org/10.1074/jbc.M610023200)

Received in final form 5 September 2019

Accepted 10 September 2019

Accepted Preprint published online 10 September 2019 (c) 2019 Society for Endocrinology Published by Bioscientifica Ltd. Printed in Great Britain 